\title{
Introduction: Rethinking Utopia in the Wake of Postmodernism
}

\author{
Alistair Fox, University of Otago, Dunedin
}

In 1998, the introduction to a special issue on the utopian thought of Fredric Jameson in the journal Utopian Studies began with a quotation from Paradise, a recently published novel by Toni Morrison:

How exquisitely human was the wish for permanent happiness, and how thin the human imagination became trying to achieve it...How can they hold it together, he wondered, this hard-won heaven defined only by the absence of the unsaved, the unworthy and the strange? (Moylan 1998, 306)

The different elements in the quotation from Toni Morrison have proved to be particularly pertinent in the opening years of the twenty-first century. It is clear that the human wish for permanent happiness persists, especially on the part of those who-like the members of diasporic transnations, or of ethnic minorities, or marginalized subcultures—-feel excluded from the affluence sought by globalized capitalism, or oppressed by the conditions that are required to achieve it. At the same time, postmodernism and its consequences have, as Jameson formulated it, deepened 'our constitutional inability to imagine Utopia itself', or at least our despair that it can ever be attained (Jameson 1982, 153).

The essays in this special issue of Portal examine ways in which the contemporary utopian impulse is expressing itself, both in the search for utopia, and through the exposure of false utopias. Many of them focus on the question of identity. Where can identity be located in a world experiencing the effects of postcolonialism, postfeminism, postmodernism, transnationalism, multiculturalism, the globalization of culture, and economic globalization? How does a given subject take up a cultural identity within a given locale or context? How is it possible to sustain a local position 
in the face of hybridity and global culture? How do the complex intersections between indigenous, local, national, diasporic, and international cultures contribute to the production and circulation of 'national' identity? Where can authenticity be located? Is it a subjective category, or a structural one? Does it have an ontological status, or merely a performative one? Is it still possible, in the circumstances of the twenty-first century, to sustain a utopian vision and construct a forward looking imaginary that is capable of shaping the future identity of a community, or nation? Finally, what should be the role of the intellectual, and of the academy itself (especially the humanities) in addressing these issues, and what would make possible effective interventions on their part?

This project has arisen out of dissatisfaction with the current state of scholarly understanding concerning these issues. Many scholars have become dissatisfied with the way that postmodernism's valorisation of heterogeneity has, paradoxically, threatened to suppress identity, rather than open up a space for it. How is it possible for the individual subject to construct an empowering, coherent sense of identity in a world defined by 'competitive interpellation' in which the subject is 'bombarded by competing messages simultaneously', when the discursive practices he or she is enjoined to follow, which are celebrated as emancipatory, lead to fragmentation and de-centred subjectivity? (Collins 1989, 143). At a macro level, something similar occurs with respect to ethnic, national, and cultural identities, which has led to questions about the viability, in human terms, of the whole postmodernist intellectual project.

Postcolonial theory, to date, has also been unable to do justice to the identity of postcolonial subjects in terms of the lived reality of their actual lives, their sense of themselves, and their aspirations. According to postcolonial theory, the distinctive identity of those who live in nation states should be disappearing as a consequence of a generalized condition of 'hybridity' resulting from the combined influence of transnational migration and the spread of First-World global culture. 'Authenticity' of identity, it is argued, is no longer feasible, because it is impossible to 'subtract a culture, a history, a language, an identity, from the wider, transforming currents of the increasingly metropolitan world' (Chambers 1994, 74). Nation states, however, are not disappearing, as witnessed by the emergence of an increasing number of 
ethnically based nation-states in certain parts of the world - for example, in Africa, the Balkans, and the former Soviet Union. Is this simply a resurgence of fascism? Or is there something more fundamental at work springing from a desire that members of a community feel to preserve their collective identity whenever they experience the real or potential threat of having it suppressed? The tenacity with which not only nation states, but also indigenous and ethnic minorities seek to assert their distinctive cultural identity suggests that, as Charles Taylor has argued, a sense of authenticity is a 'vital human need' that impinges upon one's self-esteem and sense of well-being (Taylor 1994, 26).

Some scholars are equally unhappy with the way in which postmodernist theory has led to a conceptual impasse that makes it impossible to evaluate or inspire action, especially within the political sphere. This is manifest in an erosion of agency, understood as the right of action on behalf of a belief, a cause, or a group. Feminists, for example, have argued that the postmodernist assumption that, 'all discourses are equal, with each diversity being as good as the next', means that 'there is no chance of utopia, of the universal place of the imagination', so that the emancipatory project begun in the 1960s has stalled (Grant 1994, 249). Aijaz Ahmad has also denounced the 'politics of contingency' that has arisen from the obliteration of historicity, and from the pairing of hybridity and agential displacement that he detects in certain expressions of postcolonial theory (Ahmad 1996, 286). In his exploration of postmodernism as the cultural logic of late capitalism, Fredric Jameson showed how the logic of the simulacrum, with its conversion of older realities into images and conceptual mirages, serves to abolish any practical sense of the future, and of the collective project, thus pre-empting the possibility of a socialist transformation of society (Jameson 1991).

Related to this dissatisfaction is a further dissatisfaction with the idea, promoted by James Clifford, Edward Said, and others, that intellectuals can only speak with any validity from a dis-located position; i.e. as migratory, cosmopolitan nomads, committed to no particular locality, who are able to gain true vision because of their detachment from the societies they observe. What does this say about those who are not forced into exile, or those intellectuals who choose voluntarily to remain in their home countries and commit themselves to the betterment of the local societies in 
which they live? Indeed, some people have become uneasy about the celebration of a diasporic cosmopolitan intellectual culture that seems self-congratulatory, privileged, and even parasitical in the context of a world that is still characterized by social injustice, economic exploitation, environmental destruction, the degradation of marginalized groups and minorities, and violent oppression in many places. Where has the idea of reform and social change gone in the vision of these 'gadfly' intellectuals? Increasingly, the idea that the role of the concerned intellectual is to engage with the problems of the day for the well-being of society appears to have been replaced by mere paralysis, if not a smug lassitude.

The essays included in this issue of Portal present a range of responses to these interconnected issues.

The pernicious consequences of the appropriation and commodification of indigenous and local cultures for the sake of appealing to global consumers is identified by Tania Ka'ai in her analysis of the recent film, Whale Rider, from an indigenous perspective, while Hilary Radner, through her examination of coverage of The Lord of the Rings in the New Zealand magazine Pavement, shows how a local culture can become complicit in its own subversion because of the aspiration of groups within it to constitute a community parallel and comparable to those in Europe. Conversely, Sylvie Blum-Reid, in her study of Gadjo Dilo by the Gypsy film-maker Tony Gatlif, shows how the Western urge to preserve ethnic minority cultures as if they were ethnographic collectibles is itself being interrogated by those very cultures. A significant implication of all these essays is that a critical genealogy of globalization needs to be established in order to trace the shift from European to American colonialism - if the destructive effects of globalism on local identities is to be restrained or prevented.

Issues relating to diasporic identity emerge as more problematic than is usually acknowledged by postcolonial theorists. Far from leading to assimilation through hybridity, trans-national migration is producing a new tribalism and inter-ethnic conflict in some societies (for example, the USA). Moreover, Ali Behdad observes that diasporic communities are often the most fervent supporters of nationalism in the countries of origin. On the other hand, a sense of 'arrived otherness' on the part of 
immigrants often leads to a sense of being alienated from the uniqueness of their own identity. Vijay Mishra argues that multiculturalism - which is nearly ubiquitous in Twenty-First Century societies - when it is conceived as a postmodern tolerance of heterogeneity, provides no remedy for the protection of cultural identity in societies that incorporate a number of ethnic minorities. Indeed, the doctrine of multiculturalism may be complicit in a process that obliterates the corporeality of the 'Other'. As such, it may actually be no more than a control mechanism that keeps minorities where they are in the guise of (white) respect of cultural difference without changing the unified selves of the 'managers'. What all these essays suggest is an urgent need for the realities arising from trans-national migration to be addressed more justly and effectually at the level of state policy and social practice.

In this regard, Ali Behdad in his examination of the interactions between the national and trans-nations, and David MacDonald in his investigation of the use of the Holocaust in the construction of Serbian nationalism, demonstrate how the power of the state to shape or resist the way that nations are globalised has been vastly underestimated by those who have been preaching a homogeneous 'hybridity' as the inescapable condition of postmodernity. They argue a need to unpack the relationship between 'state' and 'nation', with the relation between the national and the global being at least as important as that between the global and the local, if not more so.

Another group of essays examine how myth-making, narrativisation, symbolism, and poetry continues to be used in attempts to construct a forward-looking imaginary. Jennifer Rutherford shows how a public space has been deliberately designed in Melbourne for the purpose of re-speaking a homeland into being with a new awareness of identity. Federation Square does this, she argues, by inviting those entering into it to read and hear the suppressed histories, so that by addressing traumas from the past, those who experience the Square can 'remember forward' in order to find a new place of residence. In his analysis of the draft Constitution of the European Union, Murray Pratt reveals a further attempt at utopian myth making at a national level, but this time one that undermines itself from within. He argues that in seeking to perpetuate the idea of a culturally unified, superior set of nations fulfilling a common destiny — figured in the image of an indissoluble marriage — this document actually reveals suppressed fear that local autonomies threaten the very existence of 
the union that the document is seeking to proclaim. At the other end of the spectrum, David MacDonald, by examining the Serbian identification with the Jews as a victimized chosen people, shows the power of negative imagery to construct a dystopian national myth - in the case of Serbia, one which was used to support the genocides perpetrated against other ethnic groups under the leadership of Slobodan Milosevic.

Three of the essays in the collection explore the issue of where, and whether, utopia can be found. Two of them analyse utopian searches that are represented symbolically in the form of a journey. The first, Sylvie Blum-Reid's examination of the Gypsy road movie, Gadjo Dilo, traces an attempt to locate and preserve authentic identity, figured in the search of a young French traveller to find the elusive voice of Nora Luca, a Gypsy singer recorded by his father. She shows how the ambiguity of the film's ending, in which the protagonist buries the tapes he has gathered, raises questions as to the ethics and feasibility of attempting to capture authenticity outside the actual experience of it by those to whom it pertains. The second, Alistair Fox's analysis of Ben Okri's latest novel, In Arcadia, traces the attempt of a displaced diasporic Nigerian film-maker to find Utopia in a world fragmented by the consequences of postmodernism. He shows how Okri draws upon earlier fables to construct his own new utopian imaginary, in which Utopia is located neither in a determinate location, nor in transcendence, but in a nurturing myth of the human imagination capable of generating a constructive action within the labyrinth of this contemporary world. Speaking from an indigenous viewpoint, Sina Va'ai looks at the historical and ongoing attempts of Pacific Islands nations to redefine a new Oceania freed from the wounds of colonialism. This project, she argues, requires a decolonization of the mind, and a recognition that identity can reside in the paradox of the many in one, of which the metaphor of a 'sea of islands' is a wonderful symbol.

Finally, Feng Chongyi examines the role of the intellectual in the contemporary world, identifying the threat to that role posed by the postmodern assumption of the death of universal knowledge and truth, the specialization and professionalism that now characterizes the intellectual within the academy, and the integration of intellectuals into society's power structures. Optimistically, he concludes that despite these threats the project of the Enlightenment is not dead, and ends with a call to 
intellectuals to maintain their traditional role, even if this means working with the State and the Market, rather than in opposition to them.

Taken together, the essays in this collection are a sign not only of a growing disenchantment with globalization and the ideologies that wittingly or unwittingly underpin its ambitions, but also of the ongoing life of the utopian impulse. The essays reflect the discovery of a paradox at the heart of postmodernism: what has been celebrated as good and desirable in its intents, has, in many instances, turned out to be bad and undesirable in its effects. Whereas the heterogeneity fostered by poststructuralist theories of self and society appeared to be emancipatory, it now appears to be repressive - by obliterating cultural identity, and by serving as an instrument for the conversion of 'citizens' into mere individual subjects who define their selves through purchasing and consuming the commodities thrust before them in the global marketplace. The clear message of many of the essays is that things cannot be left to drift as they are, on a sea of relativized heterogeneity without any sense of social mission or responsibility. Even if Fredric Jameson is right in supposing that Utopia is located beyond an ever-receding vanishing point (Jameson 1998), his critics are also right to insist that utopian hope needs to be brought into a relationship with political engagement-by allowing ethics to pull 'praxis into the pragmatics of local struggles' (Moylan 1998, 5). The essays in this special issue show various efforts to do just that. Collectively, they give an accurate sense of the issues that are now engaging academics across a range of disciplines as a result of their own 'utopian imaginings' and 'productive doubt' (to use Jameson's phrases). In so doing, they indicate the opportunities and challenges that confront contemporary societies in the ongoing search for human happiness and justice.

\section{Reference List}

Ahmad, A. 1996, 'The Politics of Literary Postcoloniality', in Contemporary Postcolonial Theory: A Reader, ed. Padmini Mongia, Arnold Publishers, London and New York.

Chambers, I. 1994, Migrancy, Culture, Identity, Routledge, London.

Collins, J. 1989, Uncommon Cultures: Popular Culture and Post-Modernism, Routledge, New York and London.

Grant, L. 1994, Sexing the Millennium: Women and the Sexual Revolution, Grove Press, New York.

Jameson, F. 1998, ‘Comments’, Utopian Studies, vol. 1, Spring 1998. 
1991, Postmodernism or, The Cultural Logic of Late Capitalism, Verso, London.

1982, 'Progress Versus Utopia; or, Can We Imagine the Future?', ScienceFiction Studies, vol. 9, Part 2, no. 27 (July), 147-158.

Moylan, T. 1998, 'Jameson and Utopia' (Special Section on the Work of Fredric Jameson), Utopian Studies, vol. 1, (Spring).

Taylor, C. 1994, 'The Politics of Recognition', in Multiculturalism: Examining the Politics of Recognition, ed. Amy Gutmann, Routledge, New York. 